\section{Interferon-stimulated Gene 15 and Interferon-1 Stimulated Gene 17 Messenger RNA-based Detection of Early Pregnancy in Aardi Goats in Saudi Arabia}

\author{
Kamal Al-Samawi ${ }^{1}$, Mohamed Al-Hassan², Hussein Migdadi ${ }^{3,4 *}$, \\ Megahed Ammar ${ }^{5}$ and Salem Alghamdi ${ }^{3}$ \\ ${ }^{1}$ Animal Production Department, Faculty of Agricultural Sciences and Veterinary \\ medicine, Thamar University, Yemen Republic \\ ${ }^{2}$ Animal Production Department, College of Food and Agriculture Sciences, King \\ Saud University, KSA \\ ${ }^{3}$ Plant Production Department, College of Food and Agriculture Sciences, King \\ Saud University, KSA \\ ${ }^{4}$ National Agricultural Research Center, P.O Box: 639, Baq'a 19381, Jordan \\ ${ }^{5}$ Rice Research and Training Center, Sakha 33717, Kafrelsheikh, Egypt
}

\begin{abstract}
A B S T R A C T
The accuracy of interferon-stimulated gene 15 (ISG15) and interferon-stimulated gene 17 (ISG17) mRNA levels in early detection of pregnancy in Aardi goats compared to progesterone and ultrasound (US) were evaluated. Female goats were synchronized using the ovsynch protocol level in combination with natural mating (NM). Blood samples were collected at 1, 7, 15, 23, 35, and 60 days post NM. Levels of ISG15 and ISG17 mRNAs were assayed using real-time PCR, and serum progesterone (P4) concentrations were assayed using an ELISA kit. Pregnancy detection was performed by US on 23, 35, and 60 days post NM. Serum P4 concentration was significantly higher in pregnant than non-pregnant goats at 15, 23, 35, and 60 days post NM. Relative expression of mRNA of ISG15 and ISG17 was significantly higher in pregnant goats at 7, 15, and 35 days post NM. ISG15 and ISG17 were not significantly different compared to P4 and US in the pregnant and non-pregnant goats. The accuracy of ISG15 and ISG17 was not significantly different than P4 on days 7 and 15 or from P4 and US on day 23 post NM. Decreased accuracy of ISG15 and ISG17 on day 35 might be done to lower levels. US provided accurate pregnancy diagnoses on day $35(96.97 \%)$ and $60(100 \%)$ post NM. ISG15 and ISG17 mRNA levels could be considered good indicators of goat pregnancy on day 23 post NM. These methods will provide early and precise detection of pregnancy compared to the routinely used serum P4 and US methods.
\end{abstract}

\begin{tabular}{l} 
Article Information \\
Received 29 March 2018 \\
Revised 22 April 2019 \\
Accepted 20 February 2020 \\
Available online 26 March 2021 \\
Authors' Contribution \\
KS and MH designed and performed \\
the experiment. HM and MA analysed \\
the data and helped in reviewing the \\
manuscript. SG and HM finalized the \\
writing. \\
Key words \\
\hline $\begin{array}{l}\text { Aardi Goats, ISG15, ISG17, P4, Early } \\
\text { pregnancy detection }\end{array}$
\end{tabular}

\section{INTRODUCTION}

$\mathrm{S}$ everal methods have been used for detection of early pregnancy in goats over the past few decades. The simplest method involves observation of signs of estrus (Goel and Agrawal, 1992; Ishwar, 1995). Also abdominal ans is relatively inexpensive and easy to perform in field conditions with more than $90 \%$ accuracy 60 days post gestation (Memon and Ott, 1980). Measuring progesterone $(\mathrm{P} 4)$ is another method of indirect pregnancy detection in goats. P4 concentrations in serum or milk

\footnotetext{
* Corresponding author: hmigdadi@ksu.edu.sa; h.migdadi@gmail.com 0030-9923/2021/0003-1005 \$ 9.00/0

Copyright 2021 Zoological Society of Pakistan
}

samples can be used to determine pregnancy at 19-23 days post insemination (Al-Samawi et al., 2015). Realtime ultrasound scanning (Davey, 1986; Haibel, 1990) had an accuracy of $66 \%$ on days 17 to 19 and the accuracy reached $100 \%$ on day 34 of pregnancy (Singh et al., 2004). Pregnancy-associated glycoprotein (PAG) is useful for accurate prediction of pregnancy post day 30 (Szenci et al., 1998). The current method for detecting early pregnancy factor (EPF) uses the rosette inhibition test (RIT) which, while accurate, can be difficult to maintain and is not suitable EPF as a diagnostic tool for early pregnancy has been problematic for high-throughput diagnostic applications for example in cattle and dairy bovine (Cordoba et al., 2001; Gandy et al., 2001). Interferon-tau is a major paracrine signal produced by the bovine and ovine conceptus and acts on the endometrium 
to stimulate secondary responses that are necessary to maintain pregnancy (Roberts et al., 1992; Thatcher et al., 1995; Spencer and Bazer, 2002). Conceptus-derived interferon-tau disrupts the signal transduction pathway that regulates release of prostaglandin $\mathrm{F} 2 \alpha\left(\mathrm{PGF}_{2 \alpha}\right)$, which is the major luteolytic product in sheep, cattle, and goats (Bazer, 1992; Thatcher et al., 1995, 2001). Interferontau possesses anti-luteolytic activity and is detected in goat trophoblastic cells from 14 until $17 \mathrm{~d}$ of pregnancy (Guillomot et al., 1998). Two proteins have been detected in goats, a non-glycosylated $(17 \mathrm{kDa})$ and a glycosylated $(22-24 \mathrm{kDa})$ isoform. Proteins similar to interferon-tau have been identified in other species, including humans, which share $73 \%$ identity with ovine interferon-tau (Whaley et al., 1994). Greater expression of ISGs in the endometrium has been recently reported in pregnant cows on day 7 (Sponchiado et al., 2017). Interferon-tau also induces synthesis and secretion of an ubiquitin homolog (ubiquitin cross-reactive protein) that is called ISG15 (as described by HUGO gene nomenclature). Bovine ISG15 is released by the endometrium at times coincident with Interferon-tau release from the conceptus (Austin et al., 1996; Hansen et al., 1997, 1999; Johnson et al., 1998). Likewise, ISG15 is found in significant amount in uterine flushing from day 18 pregnant cows. Because ISG15 functions as an intracellular ubiquitin homolog (Loeb and Haas, 1992; Cunha et al., 1996; Johnson et al., 1998) and an extracellular cytokine (Recht et al., 1991; Cunha et al., 1996), detection of low blood ISG15 mRNA levels during serial collection from days 17 to 25 serves as an accurate indicator of non-pregnant cows, allowing resynchronization and insemination (Hyungchul et al., 2006). In addition, the sustained presence of conjugated ISG15 through day 50 of pregnancy might reflect stabilization of conjugated proteins in response to implantation and the development of the placenta (Kathy et al., 2004). Johnson et al. (2002) have found that ISG17 mRNA increased in the stratum compactum between days 11 and 13, and expression extended into the deep glandular epithelium and stratum spongiosum on day 15 through 17 in pregnant ewes. The present study was conducted to investigate the possibility of using ISG15 and ISG17 for early pregnancy diagnosis in Aardi goats.

\section{MATERIALS AND METHODS}

\section{Flock description}

The study was conducted for 70 days at the Research Station, Department of Animal Production, King Saud University, Riyadh, Saudi Arabia. Thirty-two healthy mature Aardi female goats (1-1.5-years old) were used in the study and six males were used for natural mating
(NM). Semen was collected and examined before males were introduced to females for NM. Animals were fed a commercial total mixed ration (ME $1950 \mathrm{kcal} \mathrm{kg-1108,}$ crude protein $13 \%$, crude fat $2 \%$, crude fiber $10 \%$, and ash $8 \%$ on DM basis; Al-wafi pellets, ARASCO, Riyadh, King Saudi Arabia). Feed was offered twice daily at 07:00 and 15:00 h, and animals had free access to clean fresh tap water throughout the study. Female goats were synchronized using the ovsynch protocol in combination with NM (Al-Samawi et al., 2015). Female goats detected in estrus intramuscular (i/m) injection of $8 \mu \mathrm{g}$ of $\mathrm{GnRH}$ (GnRH Receptal ${ }^{\circledR}$, MSD Animal Health, Upper Hutt, Wellington, New Zealand) on day 0. On day 7, goats received an $\mathrm{i} / \mathrm{m}$ injection of $10 \mathrm{mg}$ of prostaglandin $\mathrm{F}_{2 \alpha}$ (PGF Lutalyse, Pfizer Animal Health) and $48 \mathrm{~h}$ following the $\mathrm{PGF}_{2 \alpha}$ injection, they received a second $\mathrm{i} / \mathrm{m}$ injection of $8 \mu \mathrm{g}$ of $\mathrm{GnRH}$. On the same day of the $2^{\text {nd }} \mathrm{GnRH}$ treatment, hot female goats were watched and isolated. Bucks were introduced to hot female goats. Female goats were watched and mating data recorded. Day 1 of pregnancy was defined as $48 \mathrm{~h}$ from the estrous beginning.

\section{Blood samples and P4 assay}

Blood samples were collected via jugular vein at 1 , $7,15,23,35$, and 60 days post NM into vacutainer tubes. Serum was separated by centrifugation at $860 \mathrm{xg}$ for $30 \mathrm{~min}$ at $4^{\circ} \mathrm{C}$, transferred into $1.5 \mathrm{~mL}$ Eppendorf tubes, and stored at $-20^{\circ} \mathrm{C}$ until assay for $\mathrm{P} 4$. Three milliliters of whole blood were collected into Tempus tubes that contained $6 \mathrm{~mL}$ of stabilizing reagent for gene expression studies (Applied Biosystems, Foster City, CA, USA), which immediately lysed the blood cells. Tempus tubes with whole blood were vortexed for $10 \mathrm{~s}$ and stored at $-85^{\circ} \mathrm{C}$ until isolation of RNA. P4 serum concentrations were assayed after one week from samples collected. P4 serum concentrations were assayed using commercial ELISA kits (Human, Wiesbaden, Germany) and micro-titrimetric plates. The assay procedures were performed according to the manufacturer's instructions, and an automatic photometer plate reader was used for abs gene expression studies orbencies readings.

\section{RNA extraction}

Tempus tube contents were transferred to $50-\mathrm{mL}$ falcon tubes. One molar phosphate buffer saline (PBS) $(\mathrm{Ca} 2+/ \mathrm{Mg} 2+-$ free $)$ was added into the tube to bring the total volume to $12 \mathrm{~mL}$. The diluted sample was vortexed for at least $30 \mathrm{~s}$ then centrifuged at $4^{\circ} \mathrm{C}$ at $860 x g$ for $60 \mathrm{~min}$. The supernatant was carefully poured off to avoid RNA pellet loss. The tube was left inverted on absorbent paper for 1 to 2 min. An RNA isolation kit (Promega ${ }^{\circledR}$, Wisconsin, USA) was used for RNA extraction, and $175 \mu \mathrm{L}$ RNA lysis buffer 
was immediately added to samples and mixed thoroughly by inversion. Next, $350 \mu \mathrm{L}$ RNA dilution buffer was added and mixed by inverting 3-4 times and then heating at $70^{\circ} \mathrm{C}$ for $3 \mathrm{~min}$. The solution was then centrifuged at room temperature at $12,000 \mathrm{xg}$ for $10 \mathrm{~min}$; the clear lysate was transferred into a fresh tube and $200 \mu \mathrm{L} \mathrm{95 \%} \mathrm{ethanol} \mathrm{was}$ added and mixed well. The mixture was transferred to a spin basket assembly and centrifuged at room temperature at $12,000 x g$ for $1 \mathrm{~min}$; the eluate was discarded and $600 \mu \mathrm{L}$ of RNA wash solution was added. Again, the tubes were centrifuged at room temperature at $12,000 x \mathrm{~g}$ for $1 \mathrm{~min}$, the eluate discarded, and $50 \mu \mathrm{L}$ of DNase mix was added to the membrane and incubated at room temperature for $15 \mathrm{~min}$. Then, $200 \mu \mathrm{L}$ DNase stop solution was added and centrifuged at room temperature at $12,000 \mathrm{xg}$ for $1 \mathrm{~min}$. RNA wash solution $(600 \mu \mathrm{L})$ was added and centrifuged at room temperature at $12,000 \mathrm{xg}$ for $1 \mathrm{~min}$ and discarded by pouring off. Another $250 \mu \mathrm{L}$ of RNA wash solution was added, centrifuged at room temperature at 12,000xg for 2 min and transferred from the spin basket to the elution tube. Nuclease-free water $(100 \mu \mathrm{L})$ was added to the membrane, centrifuged at room temperature at $12,000 \mathrm{xg}$ for $1 \mathrm{~min}$ to elute the RNA. RNA quality was assessed using agarose gel electrophoresis; two bands appeared as shown in Supplementary Figure 1. RNA samples were stored at $-85^{\circ} \mathrm{C}$. Total RNA concentration was estimated using Nanodrop 2000 (Thermo Fisher Scientific, Inc. Waltham, MA, USA). Single-stranded cDNA was synthesized from total cellular RNA (equal volumes) using the Reverse Transcription System (Promega ${ }^{\circledR}$, Wisconsin, USA). Total RNA samples were placed in micro-centrifuge tubes and incubated at $70^{\circ} \mathrm{C}$ for $10 \mathrm{~min}$, spin at $860 \mathrm{xg}$, and placed on ice. Master mix was prepared and RNA samples were added to the master mix for a final volume of $20 \mu \mathrm{L}$, and then incubated at $42^{\circ} \mathrm{C}$ for $30 \mathrm{~min}$. The samples were heated at $95^{\circ} \mathrm{C}$ for $5 \mathrm{~min}$, and incubated at $0-5^{\circ} \mathrm{C}$ for 5 min. The first-strand cDNA synthesis reaction was diluted to $100 \mu \mathrm{L}$ with Nuclease-free water. The polymerase chain reaction (PCR) cycling program was set for 35 cycles as follows: initial denaturing at $94^{\circ} \mathrm{C}$ for $5 \mathrm{~min}$, followed by a denaturation at $94^{\circ} \mathrm{C}$ for $30 \mathrm{~s}$, then annealing at $72^{\circ} \mathrm{C}$ for $1 \mathrm{~min}$. A final extension step was performed at $72^{\circ} \mathrm{C}$ for $20 \mathrm{~min}$. The PCR product was resolved as a single band using agarose gel electrophoresis using Mini-Sub Cell Gt electrophoresis Cell (Bio-rad, Hercules, California, USA) (Supplementary Fig. 2).

\section{Quantitative real-time PCR}

Diluted cDNA $(10 \mu \mathrm{L})$ was used as a template for quantitative real-time PCR amplification using SYBR Green (Applied Biosystems, Foster City, CA, USA). The GAPDH gene was used as an internal reference for normalization (NCBI Accession no.: BC102589) for ISG15 mRNA (NCBI Accession no.: NM_174366) and ISG17 (NCBIAccession no::NM_001009735) expression. Bovine ISG15 (forward; 5'GGTATCCGAGCTGAAGCAGTT3', reverse; 5'ACCTCCCTGCTGTCA AGGT3'), ISG17 (forward; 5'GGTATCTGAGCTGAAGCAGTT3', reverse; 5'ACTTCCCTGCTGTCAAGGT3'), and GAPDH (forward; 5'GATTGTCAG CAATGCCTCCT3') reverse; (5'GGTCATAAGTCCCTCCACGA3') primers were designed to generate an amplicon size of 87 and 94 bp, respectively. ISG15 and ISG17 mRNA expression level was reported relative to GAPDH. Prediction of pregnancy based on blood ISG15 and ISG17 mRNA levels determined using -0.62 and -0.58 , respectively as the arbitrary threshold levels relative to GAPDH expression. Goats with ISG15 mRNA levels over -0.62 (relative to GAPDH) were considered pregnant, whereas those with mRNA levels under -0.62 were considered non-pregnant. Goats with ISG17 mRNA levels over -0.58 (relative to GAPDH) were considered pregnant, whereas those with mRNA levels under - 0.58 were considered non-pregnant. This level of ISG15 and ISG17 mRNA was sustained 1, $7,15,23,35$, and 60 days post natural mating (NM). RTPCR for ISG15 and GAPDH cDNA amplification was performed using 40 cycles of $95^{\circ} \mathrm{C}$ for $30 \mathrm{~s}, 62^{\circ} \mathrm{C}$ for $30 \mathrm{~s}$, and $72^{\circ} \mathrm{C}$ for $15 \mathrm{~s}$ (Applied Biosystems, Foster City, CA, USA). Following RT-PCR, cDNAs were melted (melting curve) to ensure the quality of amplification. For melting curve analysis, RT-PCR products were incubated for $10 \mathrm{~s}$ at each step with an increase in temperature of $0.5^{\circ} \mathrm{C}$ from 55 to $95^{\circ} \mathrm{C}$ in each cycle.

\section{Pregnancy detection using ultrasound}

Pregnancy was diagnosed by ultrasonography (US) (Prosound 2, ALOKA, Tokyo, Japan) on day 23 post NM using a multi-frequency linear trans-rectal probe (UST 660-7.5, ALOKA, Tokyo, Japan) and confirmed on day 35 and 60 using a multi frequency convex abdominal probe (UST-9137C, ALOKA, Tokyo, Japan). Number and sex of embryos were recorded. All pregnancies were tracked until kidding and the number and sex of kids were confirmed.

\section{Statistical analysis}

Predictions of pregnancy status using RT-PCR of ISG15 and ISG17 were compared with P4 concentration in serum, and the transrectal and transabdominal US data. The results were presented as (i) true pregnant (TP): the goat was diagnosed as pregnant and was already pregnant. (ii) False pregnant (FP): the goat was diagnosed as pregnant while it was not pregnant. (iii) True non-pregnant (TN): the goat was diagnosed as non-pregnant and was already non-pregnant. (iv) False non-pregnant (FN): the 
goat was diagnosed as non-pregnant while it was pregnant. Probability that the diagnosis of goats as non-pregnant, which is truly non-pregnant.

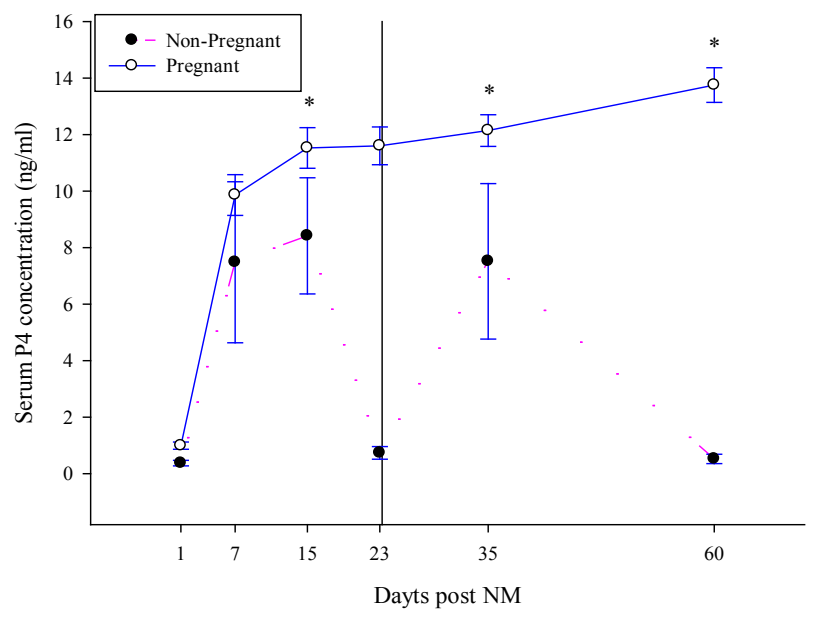

Fig. 1. Concentrations of progesterone hormone (P4) in pregnant and non-pregnant Aardi goats at 1, 7, 15, 23, 35 , and 60 days post natural mating (NM), blood samples were collected from Aardi goats, (means \pm SEM), ${ }^{*}$ denotes significant difference $(\mathrm{P}<0.01)$ between pregnant and nonpregnant goats, $(\mathrm{n}=32)$.

Sensitivity was defined as the probability that the goat diagnosed pregnant was truly pregnant, where Sensitivity $=\mathrm{TP} /([\mathrm{TP}+\mathrm{FN}] \times 100)$. Specificity was defined as the probability that the goat diagnosed non-pregnant was truly non-pregnant, where Specificity $=\mathrm{TN} /([\mathrm{TN}+\mathrm{FP}] \times 100)$. The positive predictive value (PPV): (probability that the goats are truly pregnant if the diagnosis is pregnant) was calculated as $\mathrm{PPV}=(\mathrm{TP} /[\mathrm{TP}+\mathrm{FP}] \times 100)$. The negative predictive value (NPV): (probability that the goats are truly non-pregnant if the diagnosis is non-pregnant) was calculated as NPV $=(\mathrm{TN} /[\mathrm{TN}+\mathrm{FN}] \times 100)($ Hyungchul et al., 2006). Accuracy of the diagnosis test was calculated as Accuracy $=([\mathrm{TP}+\mathrm{TN}] /[\mathrm{TP}+\mathrm{TN}+\mathrm{FN}+\mathrm{FP}] \times 100)$ (Karen et al., 2006). A general linear model (GLM) in $\mathrm{SAS}{ }^{\circledR}$ (SAS, 2003, Cary, NC, USA) was used to conduct an analysis of variance (ANOVA). A completely randomized design (CRD) was used to examine effects of pregnant and non-pregnant on ISG15, ISG17, and P4 concentrations and to examine effects of day of pregnancy on ISG15, ISG17, P4, and US. Student's $t$ test was used to examine the sensitivity, specificity, accuracy, PPV, and NPV among the early pregnancy diagnosis methods. Data were expressed as mean \pm standard error of the mean (SEM) for all parameters at a level of $\mathrm{P}<0.05$.

\section{RESULTS}

The results showed no significant difference in serum $\mathrm{P} 4$ concentrations in pregnant $(0.38 \pm 0.10,0.99 \pm 0.13$ $\mathrm{ng} / \mathrm{ml})$ and non-pregnant $(7.48 \pm 2.85,9.86 \pm 0.72 \mathrm{ng} /$ $\mathrm{ml}$ ) goats at 1 and 7 days post NM, respectively. Serum $\mathrm{P} 4$ concentrations were significantly higher $(\mathrm{P}<0.01)$ in pregnant $(11.53 \pm 0.72,11.60 \pm 0.67,12.14 \pm 0.56$, and $13.75 \pm 0.61 \mathrm{ng} / \mathrm{ml})$ than in non-pregnant $(8.42 \pm 2.06$, $0.74 \pm 0.22,7.51 \pm 2.75$, and $0.52 \pm 0.16 \mathrm{ng} / \mathrm{ml})$ goats at $15,23,35$, and 60 days post NM, respectively (Fig. 1). ISG15 mRNA expression in the blood increased post day 1, peaked on day 23, and then declined post 35 days of NM (Fig. 2A). ISG17 mRNA expression peaked on day 35 and then declined post 35 days of NM (Fig. 2B). Relative expression mRNA for ISG15 and ISG17 were significantly higher $(\mathrm{P}<0.01)$ in pregnant goats at 7,15 , and 35 days post NM compared to non-pregnant goats. No significant differences between pregnant and non-pregnant goats at 1 and 60 days post NM were detected (Fig. 2A, B). There were no significant differences in relative expression of mRNA for ISG15 or ISG17 between pregnant (Fig. 3A) and non-pregnant Aardi goats (Fig. 3B). ISG15, ISG17, P4, and US can be used to calculate PPV and NPV (Table I and II). Our results indicated non-significant differences in ISG15, ISG17, and P4 in PPV and NPV at 1, 7, and 15 days post NM. In addition, PPV and NPV were not significantly different in ISG15, ISG17, P4, and US at 23, 35 , and 60 days post NM. Sensitivity of ISG15, ISG17, and $\mathrm{P} 4$ were not significantly different at 1,7 , and 15 days post NM. ISG15, ISG17, P4, and US sensitivity were not significant different at 23 days $(58.33,58.33,76.19$, and $80.95 \%$, respectively) post NM. US sensitivity (100\%) was significantly higher $(\mathrm{P}<0.05)$ than sensitivity of ISG15, ISG17, and P4 (50.0, 50.0, and 42.86\%, respectively) at 35 days post NM. P4 sensitivity was significantly higher $(\mathrm{P}<$ $0.05)(90.48 \%)$ at 60 days post NM. In contrast, ISG15 and ISG17 sensitivity were significantly lower $(\mathrm{P}<0.05)$ at 60 days post NM (Table III). Specificity of ISG15, ISG17, and $\mathrm{P} 4$ were not significantly different at 1,7 , and 15 days post NM. In addition, specificity of ISG15, ISG17, P4, and US were not significantly different at 23,35 , and 60 days post NM (Table IV). The results show that there was no significant difference in accuracy of ISG15, ISG17, and P4 at 1,7 , and 15 days post NM, and there were no significant differences in accuracy of ISG15, ISG17, P4, and US $(65.56,65.56,75.61$, and $80.91 \%$, respectively) at 23 days post NM. However, US accuracy was significantly higher $(96.97 \%)$ on day $23(\mathrm{P}<0.01)$ than accuracy of ISG15, ISG17, and P4 (53.33, 46.67, and 50.61\%, respectively) at 35 and 60 days post NM (100\%) than ISG15 and ISG17 (37.78 and $55.56 \%$, respectively). 

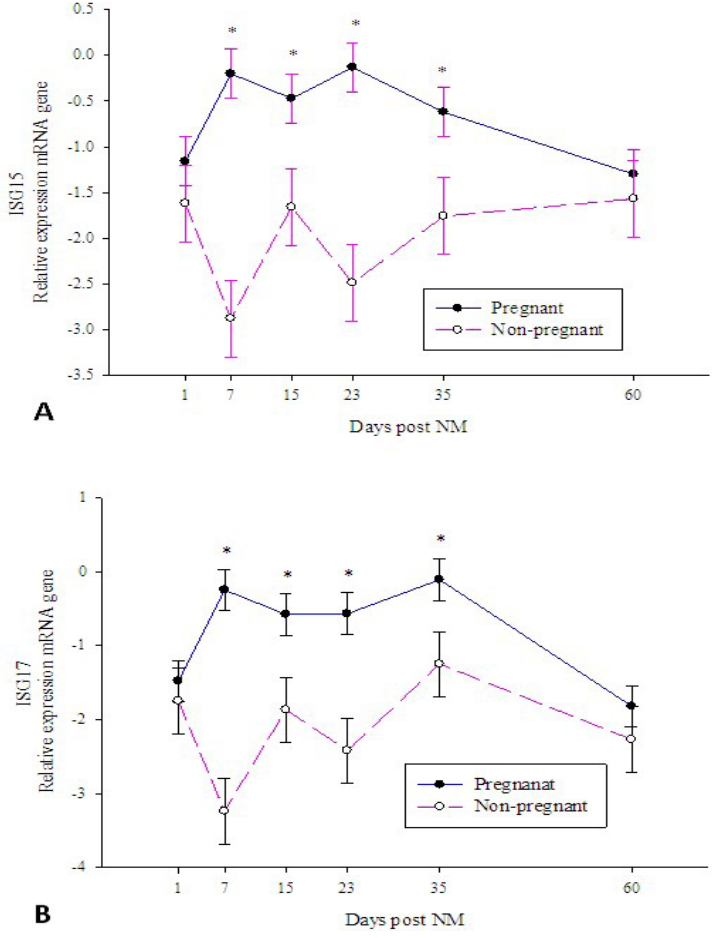

Fig. 2. Relative expression of mRNA of interferonstimulated gene 17 (ISG17) in pregnant and non-pregnant Aardi goats at $1,7,15,23,35$, and 60 days post natural mating (NM), blood samples were collected from Aardi goats, (means \pm SEM), *denotes significant difference $(\mathrm{P}<0.01)$ between pregnant and non-pregnant goats, $(\mathrm{n}=32)$.

Table I. Positive predictive value (PPV) of interferonstimulated gene 15 (ISG15), interferon-stimulated gene 17 (ISG17), progesterone hormone (P4) and ultrasound (US) for pregnancy diagnosis in goats.

\begin{tabular}{lllll}
\hline Days & \multicolumn{4}{c}{ PPV (\%) $)^{\mathbf{a}}$} \\
\cline { 2 - 5 } & ISG15 (n=17) & ISG17 (n=17) & P4 (n=32) & US (n=32) \\
\hline 1 & 66.67 & - & - & - \\
7 & 66.67 & 66.67 & 80.16 & - \\
15 & 66.67 & 66.67 & 64.72 & - \\
SEM & 29.03 & 29.03 & 9.92 & \\
23 & 66.67 & 66.67 & 83.61 & 90.28 \\
35 & 66.67 & 66.67 & 64.44 & 95.83 \\
60 & 50.00 & 100.00 & 87.03 & 100 \\
SEM & 22.29 & 22.29 & 19.93 & 19.93 \\
\hline
\end{tabular}

Means \pm SEM Means within the same row with different superscript are different $(p<0.01),(\mathrm{n}=32)$. ${ }^{\mathrm{a} P P V}$ (positive predictive value): probability that the goats are truly pregnant if the diagnosis is pregnant; correct pregnant/(correct pregnant + incorrect pregnant)*100. (Karen et al., 2006), blood samples were collected from Aardi goats, (Goats are pregnant at $\mathrm{P} 4 \geq 7.5 \mathrm{ng} / \mathrm{ml}$ )
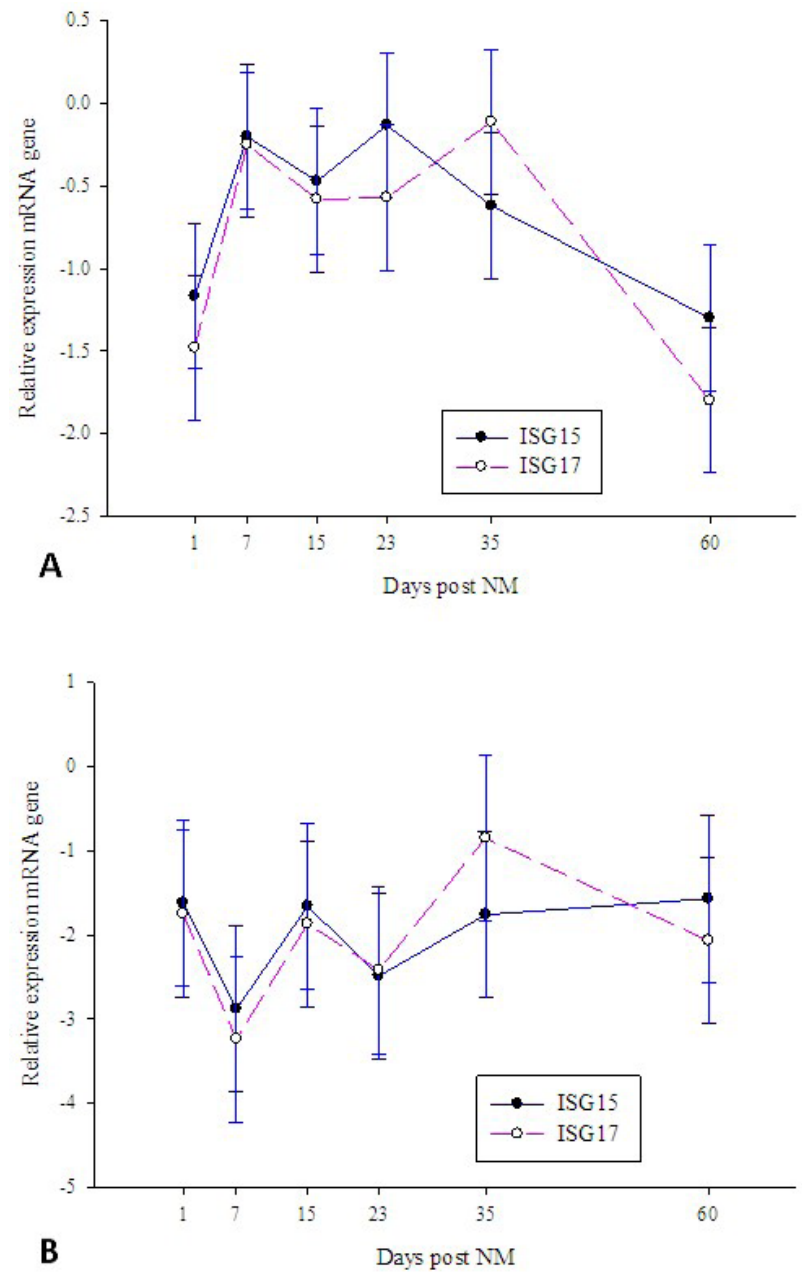

Fig. 3. Relative expression of mRNA of interferonstimulated gene 15 (ISG15) and interferon-stimulated gene 17 (ISG17) in pregnant (A) and non pregnant Aardi goats at $1,7,15,23,35$, and 60 days post natural mating (NM), blood samples were collected from Aardi goats, (means \pm SEM), $(n=32)$.

\section{DISCUSSION}

Interferons are cytokines that communicate signals for a broad spectrum of cellular activities that encompass antiviral and immunomodulatory responses, as well as growth regulation. These pleiotropic cellular activities are mediated through a large number of proteins whose expression is triggered by activated interferon receptors present on almost all cells (Boehm et al., 1997; Stark et al., 1998). All effects of interferon ${ }_{\tau}$ on ovine endometrial gene expression, both suppression of hormone receptors and up regulation of interferon-induced genes, appear to be mediated by intracellular signal transduction systems involving type I interferon receptors (Han et al., 1997; 
Table II. Negative predictive value (NPV) of interferonstimulated gene 15 (ISG15), interferon-stimulated gene 17 (ISG17), progesterone hormone (P4) and ultrasound (US) for pregnancy diagnosis in goats.

\begin{tabular}{lllll}
\hline Days & \multicolumn{4}{c}{ NPV (\%) } \\
\cline { 2 - 5 } & ISG15 (n=17) & ISG17 (n=17) & P4 (n=32) & US (n=32) \\
\hline 1 & 33.33 & 100 & 34.24 & - \\
7 & 100 & 100 & 37.50 & - \\
15 & 33.33 & 33.33 & 51.39 & - \\
SEM & 25.87 & 25.87 & 10.95 & \\
23 & 33.33 & 33.33 & 70.00 & 72.22 \\
35 & 33.33 & 33.33 & 38.89 & 100 \\
60 & 33.33 & 33.33 & 86.67 & 100 \\
SEM & 18.24 & 18.24 & 18.24 & 18.24 \\
\hline
\end{tabular}

Means \pm SEM. Means within the same row with different superscript are different $(p<0.01),(\mathrm{n}=32) .{ }^{\mathrm{a}} \mathrm{NPV}$ (negative predictive value): probability that the goats are truly non-pregnant if the diagnosis is non-pregnant; correct non-pregnant /(correct non-pregnant + incorrect non-pregnant)*100 (Karen et al., 2006), blood samples were collected from Aardi goats, (Goats are pregnant at $\mathrm{P} 4 \geq 7.5 \mathrm{ng} / \mathrm{ml}$ ).

Table III. Sensitivity of interferon-stimulated gene 15 (ISG15), interferon-stimulated gene 17 (ISG17), progesterone hormone (P4) and ultrasound (US) for pregnancy diagnosis in goats.

\begin{tabular}{lllll}
\hline Days & \multicolumn{4}{c}{ Sensitivity $(\%)^{\mathrm{a}}$} \\
\cline { 2 - 5 } & ISG15 (n=17) & ISG17 (n=17) & P4 (n=32) & US (n=32) \\
\hline 1 & 33.33 & 0 & 0 & - \\
7 & 41.67 & 41.67 & 55.36 & - \\
15 & 66.67 & 66.67 & 52.38 & - \\
SEM & 17.12 & 17.12 & 13.98 & \\
23 & 58.33 & 58.33 & 76.19 & 80.95 \\
35 & $50.00^{\mathrm{b}}$ & $50.00^{\mathrm{b}}$ & $42.86^{\mathrm{b}}$ & $100.00^{\mathrm{a}}$ \\
60 & $16.67^{\mathrm{b}}$ & $33.33^{\mathrm{b}}$ & $90.48^{\mathrm{a}}$ & $100.00^{\mathrm{a}}$ \\
SEM & 14.22 & 14.22 & 11.61 & 11.61 \\
\hline
\end{tabular}

Means \pm SEM. Means within the same row with different superscript are different $(p<0.05),(\mathrm{n}=32) .{ }^{\text {a }}$ Sensitivity: probability that diagnosis is pregnant among goats which are truly pregnant; correct pregnant/ (correct pregnant + incorrect non-pregnant)*100 (Karen et al., 2006), blood samples were collected from Aardi goats, (Goats are pregnant at $\mathrm{P} 4 \geq 7.5 \mathrm{ng} / \mathrm{ml}$ ).

Stewart et al., 2001). Interferon stimulated genes 17 (ISG17) and 15 (ISG15) are up-regulated in the uterus of ruminants, and mammals in general, in response to Interferon, the pregnancy recognition signal in ruminants (Charleston and Stewart, 1993; Ott et al., 1998; Bebington et al., 1999; Johnson et al., 1999). Yankey et al. (2001) reported that peripheral blood mononuclear cells were activated by conceptus-derived interferon-tau and expressed higher levels of MX mRNA in pregnant compared with non-pregnant sheep. It has been known for several years that ISG15 is expressed in greater levels in the endometrium of pregnant compared to non-pregnant cows (Austin et al., 1996, 2004; Johnson et al., 1998). In a study conducted to determine the impact interferoninduced gene expression in white blood cells from early pregnant cows, results showed that SG15 mRNA was upregulated in blood from pregnant to non-pregnant cows (Hyungchul et al., 2006). Study of interferon-induced gene expression in white blood cells from early pregnant goats has not been conducted until the present experiments. We tested the hypothesis that ISG15 and ISG17 mRNA were up-regulated in blood from pregnant compared to non-pregnant goats. Our results revealed that there were significantly higher ISG15 and ISG17 mRNA levels in pregnant than non-pregnant goats at 7, 15, and 35 days post NM, although no significant difference was noticed at 1 and 60 days post NM. Unfortunately, there is a lack of preexisting data regarding goats to compare with our results. Our results were in agreement with Margaret et al. (2005) who reported ISG15 mRNA was increased markedly on day 15 , concurrent with maximal secretion of interferon-tau from the conceptus in sheep. In addition, our results agree with Johnson et al. (2002) who reported both ISG17 and Mx mRNA increased between days 11 and 13, and expression extended to days 15 through 17 in pregnant ewes. Furthermore, our results are in agreement with those of Hyungchul et al. (2006), who reported that ISG15 mRNA levels increased post day 16, peaked on day 20 , and declined to day 16 levels at 32 days post artificial insemination in cows. We could not find any reference to ISG15 mRNA and ISG17 mRNA levels at 7 days post NM. Blood concentration of $\mathrm{P} 4$ in estrus is low (less than $1.0 \mathrm{ng} /$ $\mathrm{ml}$ ) through day 2 of diestrus and then quickly increases to maximum concentrations at 7 days, and remains elevated for up to days 13-15 following estrus (Rahman, 2006). Therefore, no difference between concentrations of serum P4 of both pregnant and non-pregnant occurs on days 1-7 from the estrous cycle, but regression of the corpus luteum (luteolysis), induced by prostaglandin $\mathrm{F} 2,\left(\mathrm{PGF}_{2 \alpha}\right)$, occurs if an embryo is not present in the uterus, which leads to rapid decline in plasma P4 (Rahman, 2006). Conversely, when an embryo is present in the uterus $\mathrm{PGF}_{2 \alpha}$ secretion is inhibited. Our results showed no significant differences in $\mathrm{P} 4$ concentrations between non-pregnant and pregnant goats at 1 and 7 days post NM, whereas $\mathrm{P} 4$ concentrations were significantly higher $(\mathrm{P}<0.01)$ in pregnant than nonpregnant at $15,23,35$, and 60 days post $\mathrm{NM}$, in agreement with the Zamfirescu et al. (2011). No significant differences 
were found between ISG15 and ISG17 when compared to P4 and US in the prediction of pregnant and non-pregnant goats. Additionally, no significant differences were found between ISG15 and ISG17 when compared to P4 and US in accuracy at 7, 15, and 23 days post NM. Decreased accuracy of ISG15 and ISG17 at 35 days post NM might be caused by low levels of ISG15 and ISG17.

Table IV. Specificity of interferon-stimulated gene 15 (ISG15), interferon-stimulated gene 17 (ISG17), progesterone hormone (P4) and ultrasound (US) for pregnancy diagnosis in goats.

\begin{tabular}{lllll}
\hline Days & \multicolumn{4}{c}{ Specificity (\%) } \\
\cline { 2 - 5 } & ISG15 (n=17) & ISG17(n=17) & P4 (n=32) & US (n=32) \\
\hline 1 & 80.00 & 80.00 & 100 & - \\
7 & 80.00 & 80.00 & 63.89 & - \\
15 & 80.00 & 80.00 & 55.56 & - \\
SEM & 26.64 & 26.64 & 15.38 & \\
23 & 80.00 & 80.00 & 72.22 & 80.56 \\
35 & 60.00 & 40.00 & 63.89 & 91.67 \\
60 & 80.00 & 100.00 & 75.00 & 100.00 \\
SEM & 14.83 & 14.83 & 8.56 & 8.56 \\
\hline
\end{tabular}

Means \pm SEM within the same row with different superscript are different

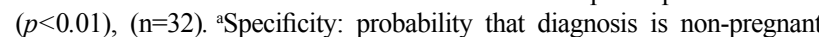
among goats which are truly non-pregnant; correct non-pregnant/(correct non-pregnant + incorrect pregnant)*100 (Karen et al., 2006), blood samples were collected from Aardi goats, (Goats are pregnant at $\mathrm{P} 4 \geq 7.5 \mathrm{ng} / \mathrm{ml}$ ).

Table V. Accuracy of interferon-stimulated gene 15 (ISG15), interferon-stimulated gene 17 (ISG17), grogesterone hormone (P4) and ultrasound (US) for pregnancy diagnosis in goats.

\begin{tabular}{|c|c|c|c|c|}
\hline \multirow[t]{2}{*}{ Days } & \multicolumn{4}{|c|}{ Accuracy $(\%)^{\mathrm{a}}$} \\
\hline & ISG15 $(n=17)$ & ISG17(n=17) & P4 $(n=32)$ & US $(n=32)$ \\
\hline 1 & 48.89 & 26.67 & 34.24 & - \\
\hline 7 & 54.44 & 54.44 & 56.67 & - \\
\hline 15 & 71.11 & 71.11 & 54.24 & - \\
\hline SEM & 15.75 & 15.75 & 15.75 & \\
\hline 23 & 65.56 & 65.56 & 75.45 & 80.91 \\
\hline 35 & $53.33^{\mathrm{b}}$ & $46.67^{b}$ & $50.61^{\mathrm{b}}$ & $96.97^{\mathrm{a}}$ \\
\hline 60 & $37.78^{b}$ & $55.56^{\mathrm{b}}$ & $84.85^{\mathrm{ab}}$ & $100^{\mathrm{a}}$ \\
\hline SEM & 12.71 & 12.71 & 12.71 & 12.71 \\
\hline
\end{tabular}

Means \pm SEM within the same row with different superscript are different $(p<0.01),(\mathrm{n}=32) .{ }^{a}$ Accuracy: The accuracy of the diagnosis test; (correct pregnant + correct non-pregnant $) /($ correct pregnant + correct non-pregnant + incorrect non-pregnant + incorrect pregnant)*100 (Karen et al., 2006), blood sampleswerecollected fromAardigoats, (GoatsarepregnantatP4 $\geq 7.5 \mathrm{ng} / \mathrm{ml}$ ).

\section{CONCLUSION}

ISG15 and ISG17 were used in the diagnosis of early pregnancy in sheep and cattle. To our knowledge, this is the first time that ISG15 and ISG17 were used for the diagnosis of early pregnancy in goats. ISG15 and ISG17 provide accurate pregnancy diagnoses at 15 and 23 days post natural mating.

\section{ACKNOWLEDGMENTS}

The authors are very grateful to the Center of scientific research college of food and agriculture sciences for financial support and to Researchers Support Services Unit at King Saud University (KSU), Riyadh, Saudi Arabia for language editing.

\section{Supplementary material}

There is supplementary material associated with this article. Access the material online at: https://dx.doi. org/10.17582/journal.pjz/20180329180335

\section{Statement of conflict of interest}

The authors have declared no conflict of interest.

\section{REFERENCES}

Al-Samawi, K.A., Al-Hassan, M.J. and Swelum A., 2015. Diagnostic reliability of enzymaticimmunoassayed serum pregnancyassociated glycoproteins in detecting early pregnancy compared to other screening measures in Aardi goats (Capra hircus) in Saudi arabia. Indian $J$. Anim. Res., 49: 680-686. https://doi.org/10.18805/ ijar.5582

Austin, K.J., Carr, A.L., Pru, J.K., Hearne, C.E., George, E.L., Belden, E.L. and Hansen, T.R., 2004. Localization of ISG15 and conjugated proteins in bovine endometrium using immunohistochemistry and electron microscopy. Endocrinology, 145: 967975. https://doi.org/10.1210/en.2003-1087

Austin, K.J., Ward, S.K., Teixeira, M.G., Dean, V.C., Moore, D.W. and Hansen, T.R., 1996. The bovine uterus in response to interferon releases ubiquitin cross reactive protein during early pregnancy. Biol. Reprod., 54: 600-606. https://doi.org/10.1095/ biolreprod54.3.600

Bazer, F.W., 1992. Mediators of maternal recognition of pregnancy in mammals. Proc. Soc. exp. Biol. Med., 199: 373-384. https://doi.org/10.3181/00379727199-43371A

Bebington, C., Doherty, F.J. and Fleming, S.D., 1999. 
Ubiquitin cross-reactive protein gene expression is increased in decidualized endometrial stromal cells at the initiation of pregnancy. Mol. Hum. Reprod., 5: 966-972. https://doi.org/10.1093/molehr/5.10.966

Boehm, U., Klamp, T., Groot, M. and Howard, J.C., 1997. Cellular responses to interferon gamma. Annu. Rev. Immunol., 15: 749-795. https://doi.org/10.1146/ annurev.immunol.15.1.749

Charleston, B. and Stewart, H.J., 1993. An interferoninduced Mx protein, cDNA sequence and high-level expression in the endometrium of pregnant sheep. Gene, 137: 327-331. https://doi.org/10.1016/03781119(93)90029-3

Cordoba, M.C., Sartori, R., Fricke, P.M., 2001.Assessment of a commercially available early conception factor (ECF) test for determining pregnancy status of dairy cattle. J. Dairy Sci., 84: 1884-1889. https://doi. org/10.3168/jds.S0022-0302(01)74629-2

Cunha, D.J., Ramanujam, S., Wagner, R.J., Witt, P.L., Knight, E.J.R. and Borden, E.C., 1996. In vitro and in vivo secretion of human ISG15, an IFN-induced immunomodulatory cytokine. J. Immunol., 157: 4100-4108.

Davey, C.G., 1986. An evaluation of pregnancy testing in sheep using a real-time ultrasound scanner. Aust. Vet. J., 6: 347-348. https://doi. org/10.1111/j.1751-0813.1986.tb02889.x

Gandy, B., Tucker, W., Williams, A., Tucker, A., Moore, A., Godfrey, R. and Willard. S., 2001. Evaluation of the early conception factor (ECFTM) test for the detection of non-pregnancy in dairy bovine. Theriogenology, 56: 637-647. https://doi. org/10.1016/S0093-691X(01)00595-7

Goel, A.K. and Agrawal, K.P., 1992. A review of pregnancy diagnosis techniques in sheep and goats. Small Ruminant Res., 9: 255-264. https://doi. org/10.1016/0921-4488(92)90155-W

Guillomot, M., Reinaud, P., La Bonnardiere, C. and Charpigny, G., 1998. Characterization of conceptusproduced goat interferon tau and analysis of its temporal and cellular distribution during early pregnancy. J. Reprod. Fertil., 112: 149-156. https:// doi.org/10.1530/jrf.0.1120149

Haibel, G.K., 1990. Use of ultrasonography in reproductive management of sheep and goat herds. Vet. Clin. N. Am. Fd. A., 9: 109-115.

Han, C.S., Mathialagan, N., Klemann, S.W. and Roberts, R.M., 1997. Molecular cloning of ovine and bovine type I interferon receptor subunits from uteri and endometrial expression of messenger ribonucleic acid for ovine receptors during the estrous cycle and pregnancy. Endocrinology, 138: 4757-4767. https:// doi.org/10.1210/endo.138.11.5530

Hansen, T.R., Austin, K.J. and Johnson, G.A., 1997. Transient ubiquitin cross-reactive protein gene expression in the bovine endometrium. Endocrinology, 138: 5079-5082. https://doi. org/10.1210/endo.138.11.5655

Hansen, T.R., Austin, K.J., Perry, D.J., Pru, J.K., Teixeira, M.G. and Johnson, G.A., 1999. Mechanism of action of interferon-tau in the uterus during early pregnancy. J. Reprod. Fertil., 54: 329-339.

Hyungchul, H., Kathleen, J.A., Lea, A.R. and Thomas, R.H., 2006. Low blood ISG15 mRNA and progesterone levels are predictive of non-pregnant dairy cows. Endocrinology, 191: 505-512. https:// doi.org/10.1677/joe.1.07015

Ishwar, A.K., 1995. Pregnancy diagnosis in sheep and goats: A review. Small Ruminant Res., 17: 37-44. https://doi.org/10.1016/0921-4488(95)00644-Z

Johnson, G.A., Austin, K.J., Van-Kirk, E.A. and Hansen, T.R., 1998. Pregnancy and interferontau induce conjugation of bovine ubiquitin crossreactive protein to cytosolic uterine proteins. Biol. Reprod., 58: 898-904. https://doi.org/10.1095/ biolreprod58.4.898

Johnson, G.A., Joyce, M.M., Yankey, S.J., Hansen1, T.R. and Ott, T.L., 2002. The interferon stimulated genes (ISG) 17 and Mx have different temporal and spatial expression in the ovine uterus suggesting more complex regulation of the Mx gene. J. Endocrinol., 174: 7-11. https://doi.org/10.1677/joe.0.174r007

Johnson, G.A., Spencer, T.E., Hansen, T.R., Austin, K.J., Burghardt, R.C. and Bazer, F.W., 1999. Expression of the interferon inducible ubiquitin cross-reactive protein in the ovine uterus. Biol. Reprod., 61: 312318. https://doi.org/10.1095/biolreprod61.1.312

Karen, A., El Amiri, B., Beckers, J.F., Sulon, J., Taverne, M.A.M. and Szenci, O., 2006. Comparison of accuracy of transabdominal ultrasonography, progesterone and pregnancy-associated glycoproteins tests for discrimination between single and multiple pregnancy in sheep. Theriogenology, 66: 314-322. https://doi.org/10.1016/j. theriogenology.2005.11.017

Kathy, J.A., Carr, A.L., Pru, J.K., Hearne, C.E., George, E.L., Belden, E.L. and Hansen, T.R., 2004. Localization of ISG15 and conjugated proteins in bovine endometrium using immunohistochemistry and electron microscopy. Endocrinology, 145: 967975. https://doi.org/10.1210/en.2003-1087

Loeb, K.R. and Haas, A.L., 1992. The interferoninducible $15-\mathrm{kDa}$ ubiquitin homolog conjugates to intracellular proteins. J. biol. Chem., 267: 7806- 
7813.

Margaret, M.J., Frankie, J.W., Robert, C.B., Jesus, J.M., Thomas, E.S., Fuller, W.B. and Greg, A.J., 2005. Interferon stimulated gene 15 conjugates to endometrial cytosolic proteins and is expressed at the uterine-placental interface throughout pregnancy in ovine. Endocrinology, 146: 675-684. https://doi. org/10.1210/en.2004-1224

Memon, M.A. and Ott, R.S., 1980. Methods of pregnancy diagnosis in sheep and goats. Cornell Vet., 70: 226231.

Ott, T.L., Spencer, T.E., Lin J.Y., Yim H.T., Gerami, B., Bartol, F.F., Wiley, A.A. and Bazer, F.W., 1998. Effects of the estrous cycle and early pregnancy on uterine expression of Mx protein in sheep (Ovis aries). Biol. Reprod., 59: 784-795. https://doi. org/10.1095/biolreprod59.4.784

Rahman, A., 2006. Hormonal changes in the uterus during pregnancy- lessons from the ewe: A review. J. Agric. Ext. Rural Dev., 4: 1-8. https://doi.org/10.3329/jard. v4i1.761

Recht, M., Borden, E.C. and Knight, E.J.R., 1991. A human $15-\mathrm{kDa}$ IFN-induced protein induces the secretion of IFN-gamma. J. Immunol., 147: 26172623.

Roberts, R.M., Cross, J.C. and Leaman, D.W., 1992. Interferons as hormones of pregnancy. Endocr. Rev., 13: 432-452. https://doi.org/10.1210/edrv-13-3-432

SAS (Statistical Analysis System), 2003. Release 9.1 for windows, SAS Institute Inc. Cary, NC, USA

Singh, N.S., Gawande, P.G., Mishra, O.P., Nema, R.K., Mishra, U.K. and Singh, M., 2004. Accuracy of ultrasonography in early pregnancy diagnosis in doe. Asian-Australas. J. Anim. Sci., 17 :760-768. https://doi.org/10.5713/ajas.2004.760

Spencer, T.E. and Bazer, F.W., 2002. Biology of progesterone action during pregnancy recognition and maintenance of pregnancy. Front. Biosci., 7: 1879-1898. https://doi.org/10.2741/A886

Sponchiado, M., Gomes, N.S., Fontes, P.K., Martins, T., del Collado, M., de Assumpcao, A., Pugliesi, G., Nogueira, M.F. and Binelli, M., 2017. Pre-hatching embryo-dependent and-independent programming of endometrial function in cattle. PloS ONE, 12: e0175954. https://doi.org/10.1371/journal. pone. 0175954

Stark, G.R., Kerr, I.M., Williams, B.R., Silverman, R.H. and Schreiber, R.D., 1998. How cells respond to interferon. Ann. Rev. Biochem., 67: 227-264. https:// doi.org/10.1146/annurev.biochem.67.1.227

Stela, Z., Andreea, A., Dorina, N. and Dobrin, N., 2011. Plasmatic profiles of pregnancy associated glycoprotein and progesterone levels during early pregnancy in carpathian goat. Ann. Rom. Soc. Cell Biol., XVI: 50-53.

Stewart, D.M., Johnson, G.A., Vyhlidal, C.A., Burghardt, R.C., Safe, S.H., Yu-Lee, L.Y., Bazer, F.W. and Spencer, T.E., 2001. Interferon activates multiple signal transducer and activator of transcription proteins and has complex effects on interferonresponsive gene transcription in ovine endometrial epithelial cells. Endocrinology, 142: 98-107. https://doi.org/10.1210/endo.142.1.7891

Szenci, O., Beckers, J.F., Humblot, P., Sulon, J., Sasser, G., Taverne, M., Varga, J., Baltusen, R. and Shekk, G., 1998. Comparison of ultrasonography, bovine pregnancy-specific protein $\mathrm{B}$, and bovine pregnancyassociated glycoprotein 1 tests for pregnancy detection in dairy cows. Theriogenology, 50: 77-88. https://doi.org/10.1016/S0093-691X(98)00115-0

Thatcher, W.W., Guzeloglu, A., Mattos, R., Binelli, M., Hansen, T.R. and Pru, J.K., 2001. Uterineconceptus interactions and reproductive failure in cattle. Theriogenology, 56: 1435-1450. https://doi. org/10.1016/S0093-691X(01)00645-8

Thatcher, W.W., Meyer, M.D. and Danet-Desnoyers, G., 1995. Maternal recognition of pregnancy Supplement. J. Reprod. Fertil., 49: 15-28.

Whaley, A.E., Meka, C.S.R., Harbison, L.A., Hunt, J.S. and Imakaw, K., 1994. Identification and cellular localization of unique interferon mRNA from human placenta. J. biol. Chem., 269: 10864-10868.

Yankey, S.J., Hicks, B.A., Carnahan, K.G., Assiri, A.M., Sinor, S.J., Kodali, K., Stellflug, J.N. and Ott, T.L., 2001. Expression of the antiviral protein $\mathrm{Mx}$ in peripheral blood mononuclear cells of pregnant and bred, non-pregnant ewes. J. Endocrinol., 170: R7R11. https://doi.org/10.1677/joe.0.170r007

Zamfirescu, S., Anghel, A., Nadolu, D. and Dobrin, N., 2011. Plasmatic profiles of pregnancy-associated glycoprotein and progesterone levels during early pregnancy in carpathian goat. Ann. RSCB., 16: 5053. 